\title{
Effect of heart failure on catecholamine granule morphology and storage in chromaffin cells
}

\author{
Sushil K Mahata', Hong Zheng ${ }^{2}$, Sumana Mahata3 ${ }^{3}$ Xuefei Liư ${ }^{2}$ and Kaushik P Patel${ }^{2}$ \\ IVA San Diego Healthcare System Metabolic Physiology \& Ultrastructural Biology Lab., Department of \\ Medicine, University of California at San Diego, La Jolla, CA, USA \\ 2Department of Cellular and Integrative Physiology, University of Nebraska Medical Center, Omaha, NE, USA \\ ${ }^{3}$ Caltech Division of Biology, California Institute of Technology, Pasadena, CA, USA
}

Correspondence should be addressed to K P Patel Email kpatel@unmc.edu

\begin{abstract}
One of the key mechanisms involved in sympathoexcitation in chronic heart failure (HF) is the activation of the adrenal glands. Impact of the elevated catecholamines on the hemodynamic parameters has been previously demonstrated. However, studies linking the structural effects of such overactivation with secretory performance and cell metabolism in the adrenomedullary chromaffin cells in vivo have not been previously reported. In this study, HF was induced in male Sprague-Dawley rats by ligation of the left coronary artery. Five weeks after surgery, cardiac function was assessed by ventricular hemodynamics. HF rats showed increased adrenal weight and adrenal catecholamine levels (norepinephrine, epinephrine and dopamine) compared with sham-operated rats. Rats with HF demonstrated increased small synaptic and dense core vesicle in splanchnic-adrenal synapses indicating trans-synaptic activation of catecholamine biosynthetic enzymes, increased endoplasmic reticulum and Golgi lumen width to meet the demand of increased catecholamine synthesis and release, and more mitochondria with dilated cristae and glycogen to accommodate for the increased energy demand for the increased biogenesis and exocytosis of catecholamines from the adrenal medulla. These findings suggest that increased trans-synaptic activation of the chromaffin cells within the adrenal medulla may lead to increased catecholamines in the circulation which in turn contributes to the enhanced neurohumoral drive, providing a unique mechanistic insight for enhanced catecholamine levels in plasma commonly observed in chronic HF condition.
\end{abstract}

\author{
Key Words \\ - catecholamines \\ - chromaffin cells \\ - heart failure \\ - sympathetic activation
}

\section{Introduction}

Enhanced neurohumoral drive is a major risk factor that influences the progression of chronic heart failure (HF) and mortality in patients and the experimental models (Packer 1988, Zucker et al. 1995, Patel 1997). During HF, enhanced levels of catecholamines resulting from activation of the sympathetic nervous system ensure an increase in cardiac function, to achieve an adaptation of the cardiac output to the systemic needs. However, long-term stimulation of catecholamines becomes harmful, contributing to the progression of HF. Although most therapeutic pharmaceutical strategies target the peripheral symptoms of the disease, they may http://joe.endocrinology-journals.org DOI: 10.1530/JOE-16-0146
C 2016 Society for Endocrinology Published by Bioscientifica Ltd. Printed in Great Britain

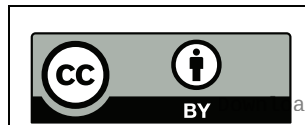

This work is licensed under a Creative Commons Attribution 3.0 Unported License.
Journal of Endocrinology (2016) 230, 309-323 
not influence the enhanced sympathetic nerve activity. Indeed, various studies have detailed the role of cardiac and hemodynamic mechanisms involved in the elevated sympathetic drive in HF (Packer 1988, Ferguson et al. 1990, Brändle et al. 1996, Patel 1997). The role of the adrenal gland in the development of sympathetic overactivation and progression of HF is less well known.

Circulating catecholamines, comprising dopamine (DA), norepinephrine (NE) and epinephrine (EPI), are primarily synthesized and released from the chromaffin cells of the adrenal medulla (Goldstein et al. 2003). Under physiological (nonstress) conditions, the adrenal medulla secretes $\sim 80 \%$ of EPI and $\sim 20 \%$ of NE (Tank \& Lee Wong 2015). While EPI is secreted exclusively from the adrenal medulla, the major source of circulating $\mathrm{NE}$ is from sympathetic nerve endings (Goldstein et al. 2003). Plasma DA comes from the adrenal medulla, sympathetic nerve endings and the brain. Resting levels of plasma catecholamines range from 25 to $70 \mathrm{pg} / \mathrm{mL}$ for DA, 200 to $300 \mathrm{pg} / \mathrm{mL}$ for $\mathrm{NE}$ and 30 to $70 \mathrm{pg} / \mathrm{mL}$ for EPI (Tank \& Lee Wong 2015). Although plasma DA concentration is similar to those of EPI, circulating DA does not act as a hormone because of its much lower potency. Plasma concentrations of NE and EPI increase dramatically in response to physical, psychological or environmental stress, exercise, exposure to cold or low oxygen tension or fear and alarm to counteract with the stress (Tank \& Lee Wong 2015). This biological response of catecholamines is considered as an adaptive response.

The contribution of adrenal catecholamines to the progression of HF has been documented in a few experimental models (Lymperopoulos et al. 2010, Schneider et al. 2011). Adrenal gland hypertrophy has been reported in rats after experimental myocardial infarction (Schneider et al. 2011). Mice lacking $\alpha_{2 C}$-adrenoceptors which control EPI secretion in adrenal chromaffin cells show rapid deterioration of cardiac function and raised mortality after transverse aortic constriction (de Lucia et al. 2014). Interestingly, reduction in sympathetic activity via adrenal-targeted G-protein-coupled receptor kinase 2 (GRK2) gene deletion attenuates HF progression and improves cardiac function after myocardial infarction (Lymperopoulos et al. 2010). Therapeutic strategies such as $\beta$-blocker and exercise training have been reported to improve outcome in HF, likely by lowering HF-dependent sympathetic nervous system hyperactivity, and at least in part, via reduction in adrenal catecholamine hypersecretion (Rengo et al. 2010, de Lucia et al. 2014).
Elevated levels of circulating catecholamines have been reported in both patients with HF and animals with experimental HF (Cohn et al. 1984, Kleiber et al. 2008). Under the stress condition, the increase in plasma EPI is derived almost completely from the adrenal medulla, whereas about $70 \%$ plasma NE is derived from sympathetic nerves (Kvetnansky et al. 1979). Exaggerated sympathetic nerve activation is a major risk factor that influences the progression of HF and mortality in patients. High levels of plasma NE in patients with HF have been known to have very poor prognosis (Cohn et al. 1984). Although most therapeutic pharmaceutical strategies target the peripheral symptoms of the disease, they may not influence the overall enhanced sympathetic activation. Reducing the adrenergic drive is important, as $\mathrm{HF}$ patients with lower levels of plasma NE are given a better prognosis (Cohn et al. 1984). However, the adrenal medullary contribution and alterations for the origin of catecholamines in the circulation during HF condition are not fully explored to date. Thus, we hypothesized that the structural effects of secretory performance and cell metabolism in the adrenal medullary chromaffin cells may lead to increased catecholamines in the circulation which in turn contributes to the enhanced neurohumoral drive commonly observed in the HF condition.

\section{Materials and methods}

\section{Study approval}

All the procedures on animals in this study were approved by the University of Nebraska Medical Center Institutional Animal Care and Use Committee. The experiments were conducted according to the American Physiological Society guiding principles for research involving animals and human beings and the NIH guide for the care and use of laboratory animals.

\section{Induction of heart failure}

Male Sprague-Dawley rats weighing 200-220g were obtained from Sasco Breeding Laboratories (Omaha, NE, USA) and were randomly assigned to a sham-operated group and an HF group. HF was produced by coronary artery ligation, as described previously (Zhang et al. 2001, Kleiber et al. 2008). Each rat was caged individually in an environment with ambient temperature maintained at $22^{\circ} \mathrm{C}$ and humidity at $30-40 \%$. Laboratory chow and tap water were available ad libitum.

Published by Bioscientifica Ltd. 
Table 1 Primer sequences used for quantitative real-time PCR analysis.

\begin{tabular}{|c|c|}
\hline Gene & Primer sequence \\
\hline $\mathrm{TH}$ & $\begin{array}{l}\text { Sense: CTGGGTGCACTTGTCTGTGCAGT } \\
\text { Antisense: CAGTACACCGTGGAGAG }\end{array}$ \\
\hline $\mathrm{D} \beta \mathrm{H}$ & $\begin{array}{l}\text { Sense: CACCACATCATCATGTATGAGG } \\
\text { Antisense: CCTGTCTGTGCAGTAGCCAG }\end{array}$ \\
\hline PNMT & $\begin{array}{l}\text { Sense: TACCTCCGCAACAACTACGC } \\
\text { Antisense: AAGGCTCCTGGTTCCTCTCG }\end{array}$ \\
\hline GAPDH & $\begin{array}{l}\text { Sense: TGACAACTCCCTCAAGATTTGTCA } \\
\text { Antisense: GGCATGGACTGTGGTCATGA }\end{array}$ \\
\hline
\end{tabular}

The degree of left ventricular dysfunction and HF were determined using both hemodynamic and anatomic criteria. Echocardiograms were performed at 5 weeks after surgery. Left ventricular end-diastolic pressure (LVEDP) was measured using a Mikro-Tip catheter (Millar Instruments, Houston, TX, USA) at the time of the terminal experiment. To measure infarct size, the heart was dissected and the atria and right ventricle were removed. A digital image of the left ventricle was captured using a digital camera. The percentage of infarct area to total left ventricle area was quantified using SigmaScan Pro (Aspire Software International, Ashburn, VA, USA). Rats with both LVEDP $>15 \mathrm{mmHg}$ and infarct size $>30 \%$ of total left ventricular wall were considered to be in HF. Sham-operated rats were treated similarly as the HF rats except that their coronary arteries were not ligated.

\section{Adrenal catecholamine measurements}

The adrenal glands were harvested from each animal immediately after killing. These samples were weighed, homogenized in cold perchloric acid containing ethylenediaminetetraacetic acid and centrifuged at $4^{\circ} \mathrm{C}$ for $15 \mathrm{~min}$ at $15,000 \mathrm{~g}$. The supernatants were stored at $-70^{\circ} \mathrm{C}$ until they were assayed for catecholamines.
Table 2 The characteristics of sham and HF rats.

\begin{tabular}{l} 
Measures \\
\hline Body weight $(\mathrm{g})$ \\
Heart weight $(\mathrm{g})$ \\
Infarct size $(\%$ of epicardial LV) \\
LVEDP $(\mathrm{mmHg})$ \\
Ejection fraction, \% \\
$\mathrm{dP} / \mathrm{dt}, \mathrm{mmHg} / \mathrm{s}$ \\
$-\mathrm{dP} / \mathrm{dt}, \mathrm{mmHg} / \mathrm{s}$
\end{tabular}

\begin{tabular}{|c|c|}
\hline Sham & HF \\
\hline $416 \pm 14$ & $457 \pm 13^{*}$ \\
\hline $1.2 \pm 0.1$ & $2.4 \pm 0.2^{*}$ \\
\hline 0 & $34 \pm 2^{*}$ \\
\hline $2 \pm 1$ & $24 \pm 5^{*}$ \\
\hline $81 \pm 5$ & $51 \pm 5^{*}$ \\
\hline $8549 \pm 663$ & $5102 \pm 364^{*}$ \\
\hline$-6836 \pm 346$ & $-4637 \pm 298^{*}$ \\
\hline
\end{tabular}

Values are mean \pm s.E. ${ }^{*} P<0.05$ versus sham; $n=8 /$ group. LV left ventricle, LVEDP left ventricular end-diastolic pressure.

DA, NE and EPI concentrations were assayed using alumina extraction followed by separation and analysis with HPLC and electrochemical detection (Bioanalytical Systems, West Lafayette, IN, USA). Dihydroxybenzylamine (Sigma) was used as an internal standard in each tissue sample (Kline et al. 1986).

\section{Urinary norepinephrine excretion measurement}

Urinary NE excretion was measured as an index of overall sympathetic activation. Five weeks after surgery, rats from all groups were placed in metabolic cages and urine was collected for $24 \mathrm{~h}$. Urinary NE concentration of thawed samples was measured using a commercially available ELISA kit (Labor Diagnostika Nord, Nordhorn, Germany), following the manufacturer's instructions.

\section{Real-time RT-PCR and Western blot measurement of catecholamine biosynthetic enzymes in the adrenal gland}

The half adrenal gland was placed in $500 \mu \mathrm{L}$ Tri-Reagent (Molecular Research Center Inc, OH, USA), followed by extraction of mRNA. The other half of adrenal gland
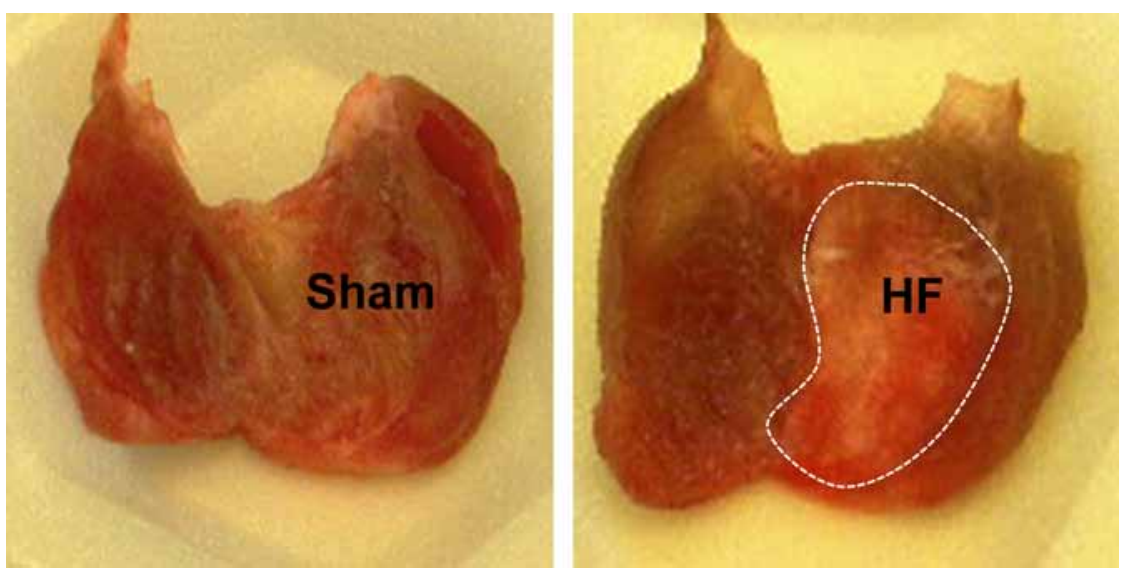

Figure 1

A representative image of the left ventricle from one sham and one HF rat. Circled area indicates infarcted area of the heart in the HF rat. There was no such area in the sham rat. A full colour version of this figure is available at http://dx.doi. org/10.1530/JOE-16-0146. http://joe.endocrinology-journals.org
DOI: 10.1530/JOE-16-0146
๑ 2016 Society for Endocrinology Printed in Great Britain
Published by Bioscientifica Ltd 
was placed in $150 \mu \mathrm{L}$ RIPA lysis buffer to extract the protein. Real-time RT-PCR measurements were made with the iCycler iQ Multicolor Real-Time Detection System (Bio-Rad). The reaction mixture consisted of SYBR Green Supermix (Bio-Rad), 300 nM sense and antisense primers, and the cDNA template of interest (for primer sequences see Table 1). Relative expression of tyrosine hydroxylase $\mathrm{TH}$, the rate limiting enzyme in catecholamine biosynthesis, which converts tyrosine to L-Dopa), dopamine- $\beta$-hydroxylase $(\mathrm{D} \beta \mathrm{H}$, which converts dopamine to $\mathrm{NE}$ ) and phenylethanolamine $\mathrm{N}$-methyltransferase (PNMT, which converts NE to EPI) mRNA was calculated with the Pfaffl equation, which relates the expression of the target gene to the expression of reference gene: glyceraldehyde 3-phosphate dehydrogenase (GAPDH).

The protein samples were loaded onto an SDSPAGE gel and subjected to electrophoresis. The fractionated proteins on the gel were transferred to a polyvinylidene difluoride membrane (Millipore). The membrane was probed with primary antibody (rabbit anti-TH (1:500), D $\beta H \quad(1: 500)$ and PNMT (1:1000) (Abcam) or mouse anti- $\beta$-actin (1:1000, Santa Cruz)) overnight, and then probed with secondary antibody (peroxidase-conjugated anti-rabbit or goat IgG, 1:5000, Pierce). An enhanced chemiluminescence substrate (Pierce) was applied to the membrane, followed by an exposure within an UVP system (UVP BioImaging, CA, USA) for visualization. Kodak 1D software (Kodak) was used to quantify the signal. The expression of protein was calculated as the ratio of intensity of the TH, D $\beta \mathrm{H}$ and PNMT bands, respectively, relative to the intensity of $\beta$-actin band.

\section{Transmission electron microscopy (TEM)}

Five weeks after surgery, rats were anesthetized with pentobarbital $(150 \mathrm{mg} / \mathrm{kg}$, i.p.) and perfused transcardially with $\mathrm{Ca}^{2+}$ - and $\mathrm{Mg}^{2+}$-free buffer composed of Dulbecco's phosphate-buffered saline, $10 \mathrm{mM}$ HEPES, $0.2 \mathrm{mM}$ ethylene glycol tetraacetic acid, $0.2 \%$ bovine serum albumin, $5 \mathrm{mM}$ glucose and $9.5 \mathrm{mM} \mathrm{KCl}$ following the fixative containing $2.5 \%$ glutaraldehyde, $2 \%$ paraformaldehyde in $0.15 \mathrm{M}$ cacodylate buffer as described previously (Pasqua et al. 2016). The adrenal gland was removed, sliced into small pieces and postfixed in the same fixative at $4^{\circ} \mathrm{C}$ overnight. The adrenal slices were stained en bloc with 2-3\% uranyl acetate for $1 \mathrm{~h}$ on ice, dehydrated in graded series of ethanol (20-100\%) on ice followed by one wash with $100 \%$ ethanol and two washes with acetone ( $15 \mathrm{~min}$ each) and embedded
A

Adrenal weight

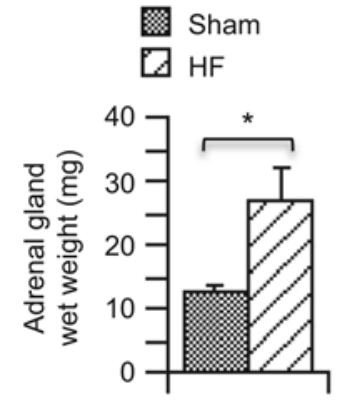

B
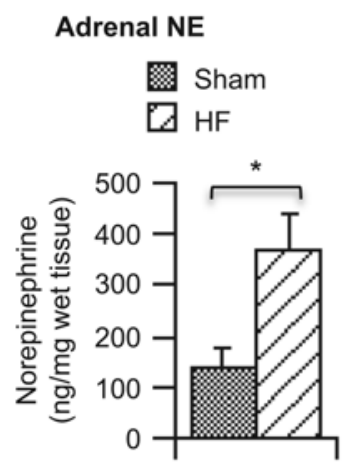

C

Adrenal EPI

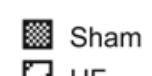

D HF

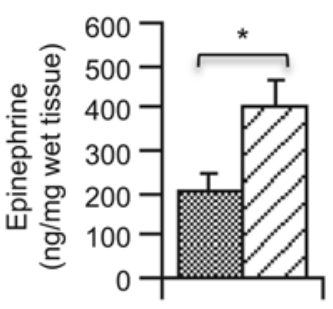

D

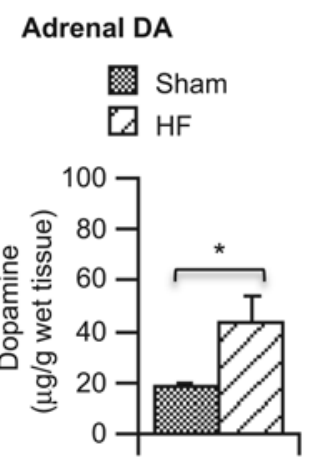

E
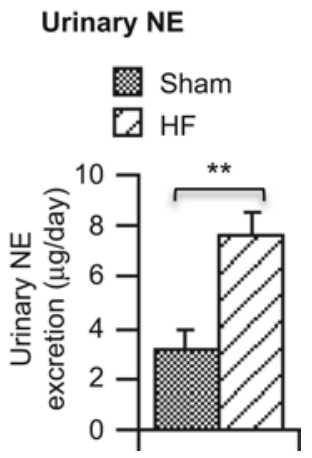

Figure 2

Gravimetry and catecholamine content in sham-operated and HF rats. (A) Weight of the adrenal gland (mg). (B) Adrenal NE content.

(C) Adrenal EPI content. (D) Adrenal dopamine (DA) content. (E) Urinary NE level. ${ }^{*} P<0.05 ; * * P<0.01$.

with Durcupan. Sections (50-60 nm thick) were cut on a Leica UCT ultramicrotome, picked up on Formvar and carbon-coated copper grids, and stained with $2 \%$ uranyl acetate for $5 \mathrm{~min}$ and Sato's lead stain for $1 \mathrm{~min}$. Grids were viewed using a JEOL 1200EX II (JEOL, Peabody, MA, USA) TEM and photographed using a Gatan digital camera (Gatan, Pleasanton, CA, USA). Micrographs were randomly taken from three adrenal glands each from sham and HF rats.

Published by Bioscientifica Ltd. 
A

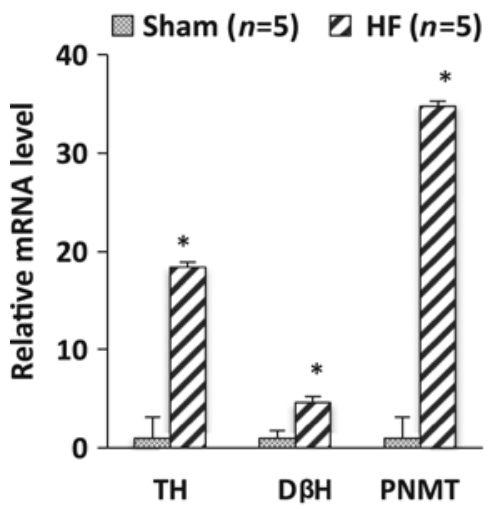

B

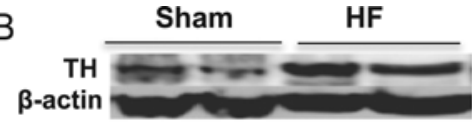

\section{$\mathrm{D} \beta \mathrm{H}$} $\beta$-actin

PNMT $\beta$-actin

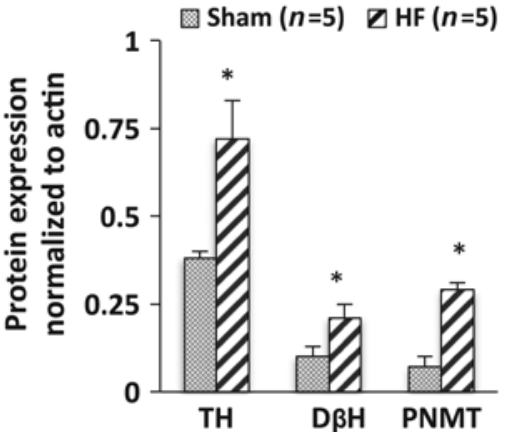

$56 \mathrm{kDa}$

$43 \mathrm{kDa}$

$43 \mathrm{kDa}$

$31 \mathrm{kDa}$

$43 \mathrm{kDa}$

\section{Morphometric analysis}

Samples were blinded and two people did measurements randomly from different cells. The line segment tool in ImageJ was used to measure diameters (large dense core vesicle-LDCV, small dense core vesicle-SDCV and small synaptic vesicle-SSV), length (mitochondria) and lumen width (endoplasmic reticulum-ER, Golgi and cristae). The free-hand tool was used to manually trace around the vesicle membrane (LDCV, SDCV and SSV) and mitochondrial outer membrane area and cytoplasm area. For determination of the volume density (\%) of vesicles and mitochondria, the sum of the area of the vesicles or mitochondria was divided by the area of the cytoplasm and multiplied by 100 as described previously (Pasqua et al. 2016).
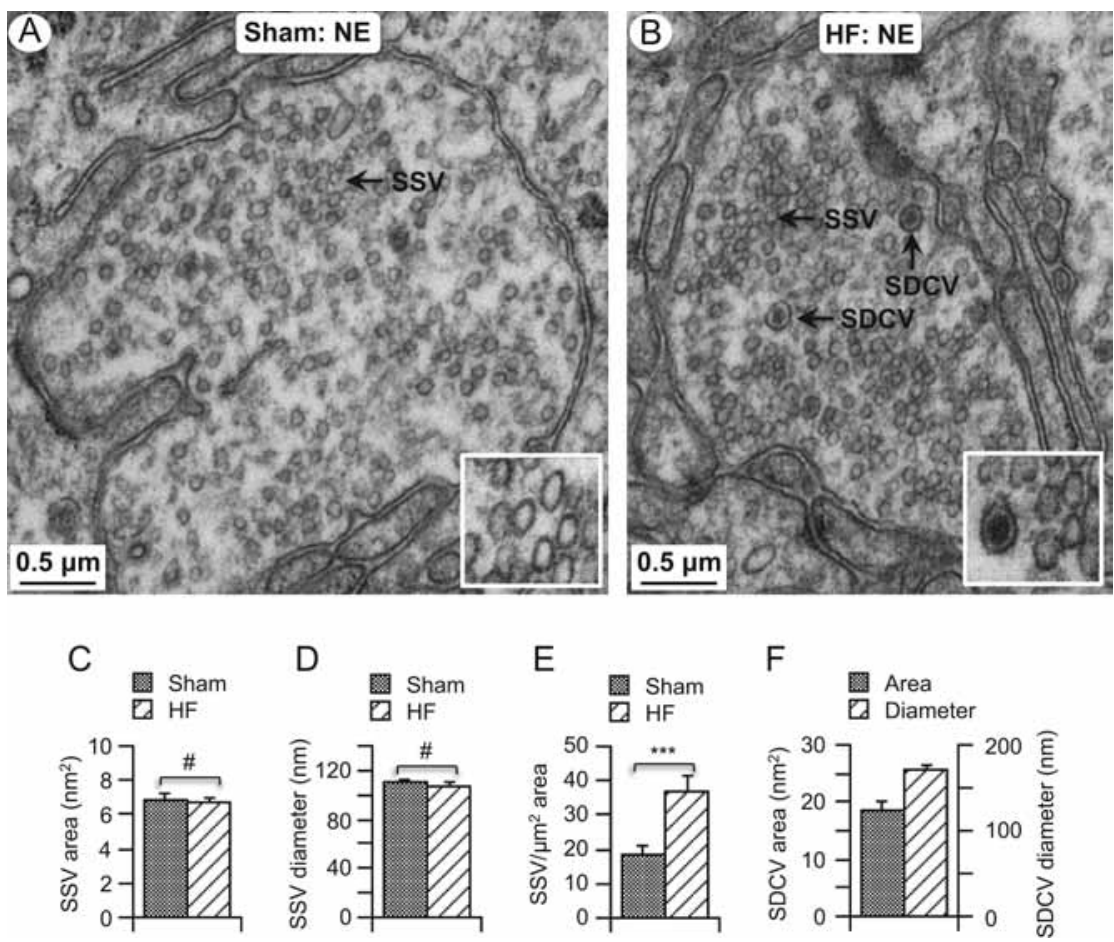

\section{Figure 3}

Expression of $\mathrm{TH}, \mathrm{D} \beta \mathrm{H}$ and $\mathrm{PNMT}$ in the adrenal (A) TH, D $\beta H$ and measured by real-time PCR in sham and HF rats (B) Protein levels of $\mathrm{TH}, \mathrm{D} \beta \mathrm{H}$ and PNMT in sham and $\mathrm{HF}$ rats. ${ }^{*} P<0.05 ; * * P<0.01$.

\section{Figure 4}

Low-magnification ( $\times 2500$ original magnification) TEM photographs of the axon terminal. (A) Axon terminal in NE cells of sham-operated rat. (B) Axon terminal in NE cells of HF rat. Morphometric analyses ( 30 nerve terminals in 30 chromaffin cells from 3 each of the sham-operated and HF rats). (C) SSV area $\left(\mathrm{nm}^{2}\right)$. (D) SSV diameter (nm). (E) SSV per $\mu \mathrm{m}^{2}$ area of the synapse. (F) SDCV area $\left(\mathrm{nm}^{2}\right)$ and SDCV diameter (nm). SDCV, small dense core vesicle; SSV, small synaptic vesicle. ${ }^{* * *} P<0.001, \#$ : not significant.

http://joe.endocrinology-journals.org DOI: 10.1530/JOE-16-0146
๑) 2016 Society for Endocrinology Printed in Great Britain 

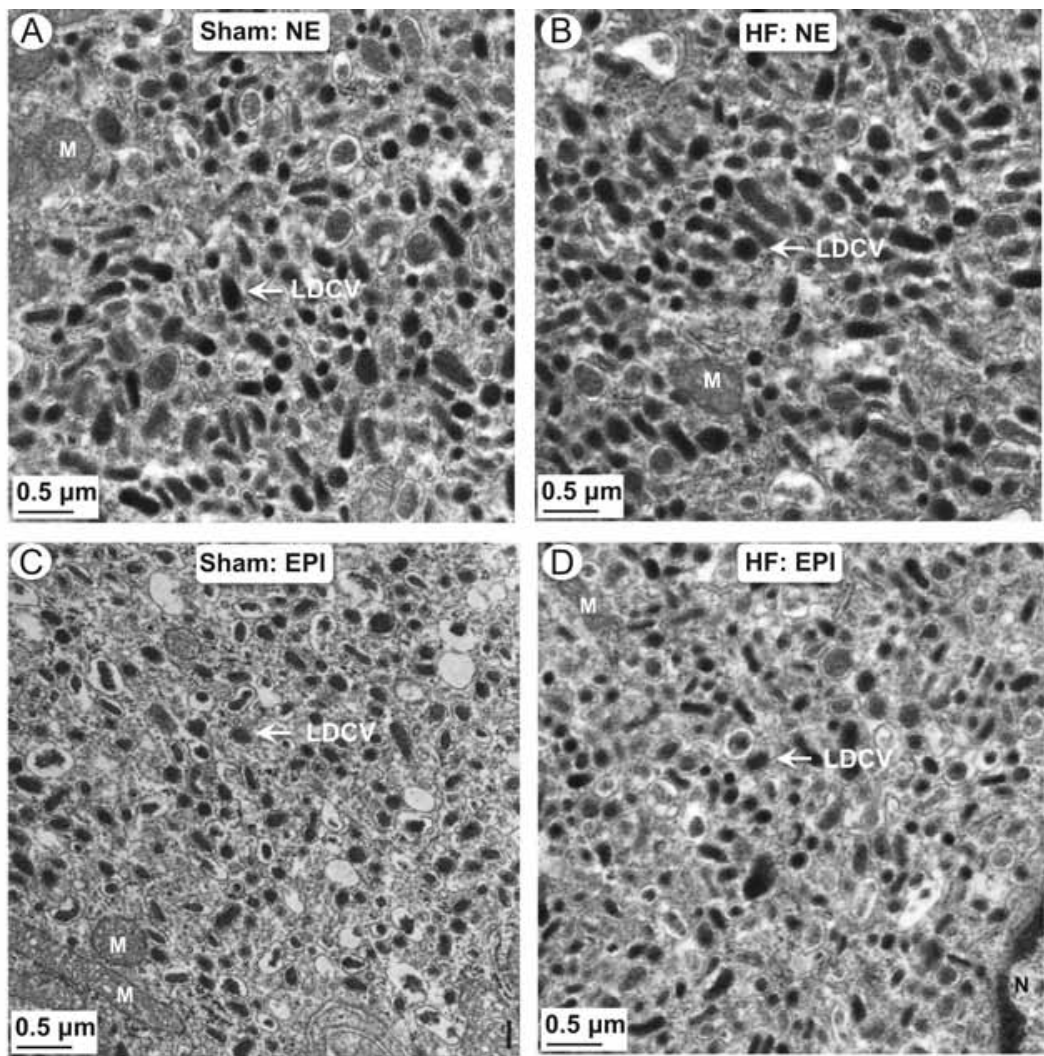

E

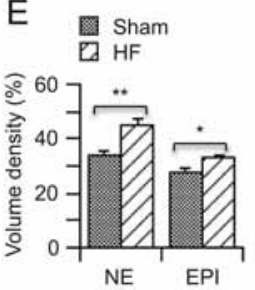

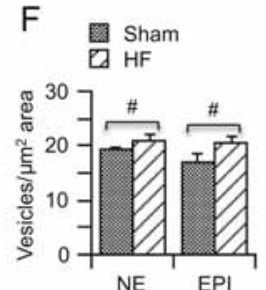
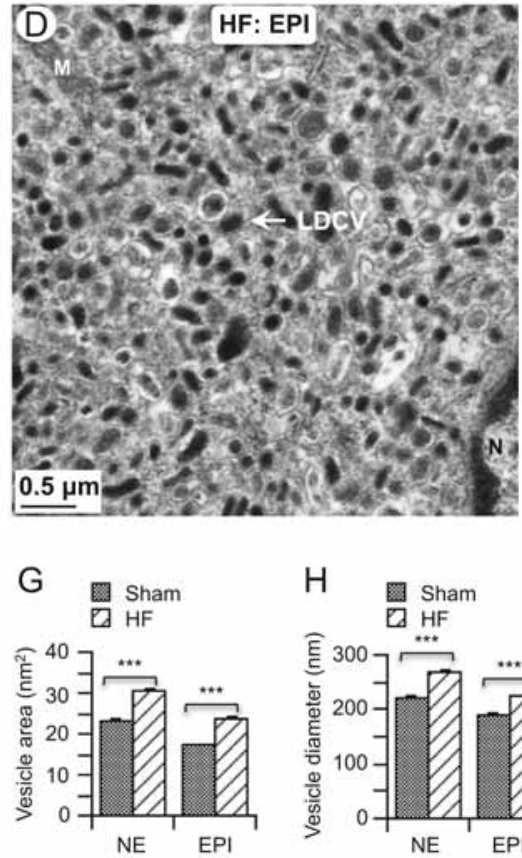

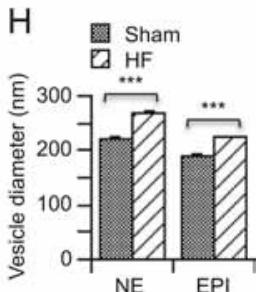

\section{Figure 5}

Low-magnification ( $\times 2500$ original magnification) TEM photographs of the adrenal medulla. (A) Adrenal medulla showing NE cells with LDCV in a sham-operated rat. (B) Adrenal medulla showing NE cells with LDCV in an HF rat. (C) Adrenal medulla showing EPI cells with LDCV in a sham-operated rat. (D) Adrenal medulla showing EPI cells with LDCV in an HF rat. Morphometric analyses (650 vesicles total from 3 each of the sham-operated and HF rats): (E) Volume densities (\%) of LDCV. (F) Number of LDCVs per $\mu \mathrm{m}^{2}$ area of the cytoplasm. (G) Vesicle area $\left(\mathrm{nm}^{2}\right)$ of NE-LDCV and EPI-LDCV. (H) LDCV diameter $(\mathrm{nm})$ in NE-LDCV and EPI-LDCV. ${ }^{*} P<0.05 ;{ }^{*} P<0.01 ; * * * P<0.001$ and \#: not significant.

\section{Data presentation and statistical analysis}

Data are expressed as mean \pm s.E.M. Statistical analyses were performed using Student's t-tests, KolmogorovSmirnov test as well as one-way ANOVA followed by Dunnett's post hoc test when appropriate. Statistical significance was defined as $P<0.05$. Statistics were computed with the software package, Prism 7 (GraphPad Software, San Diego, CA, USA).

\section{Results}

\section{General characteristics}

Table 2 presents general characteristics and left ventricular function parameters among the experimental groups. The body weight and whole heart weight was significantly increased in HF group. Only rats with $>30 \%$ infarct of the left ventricular wall were included in the study. Shamoperated rats had no visible myocardial damage (Fig. 1). Ejection fraction was significantly lower in HF group. LVEDP was significantly increased in the $\mathrm{HF}$ rats compared with sham group. HF rats had significantly 'lower change in pressure over time' $(+\mathrm{dP} / \mathrm{dt}$ and $-\mathrm{dP} / \mathrm{dt}$ ) compared with sham rats suggesting reduced contractility/relaxation. These data confirm that these rats in the HF groups were experiencing cardiac dysfunction as shown in greater detail before (Patel et al. 2000, Zhang et al. 2001, Kleiber et al. 2008).

\section{Increased adrenal weight and adrenal catecholamines in HF rats}

Consistent with prolonged stress, adrenal glands were heavier in HF rats compared with sham-operated rats

Published by Bioscientifica Ltd. 

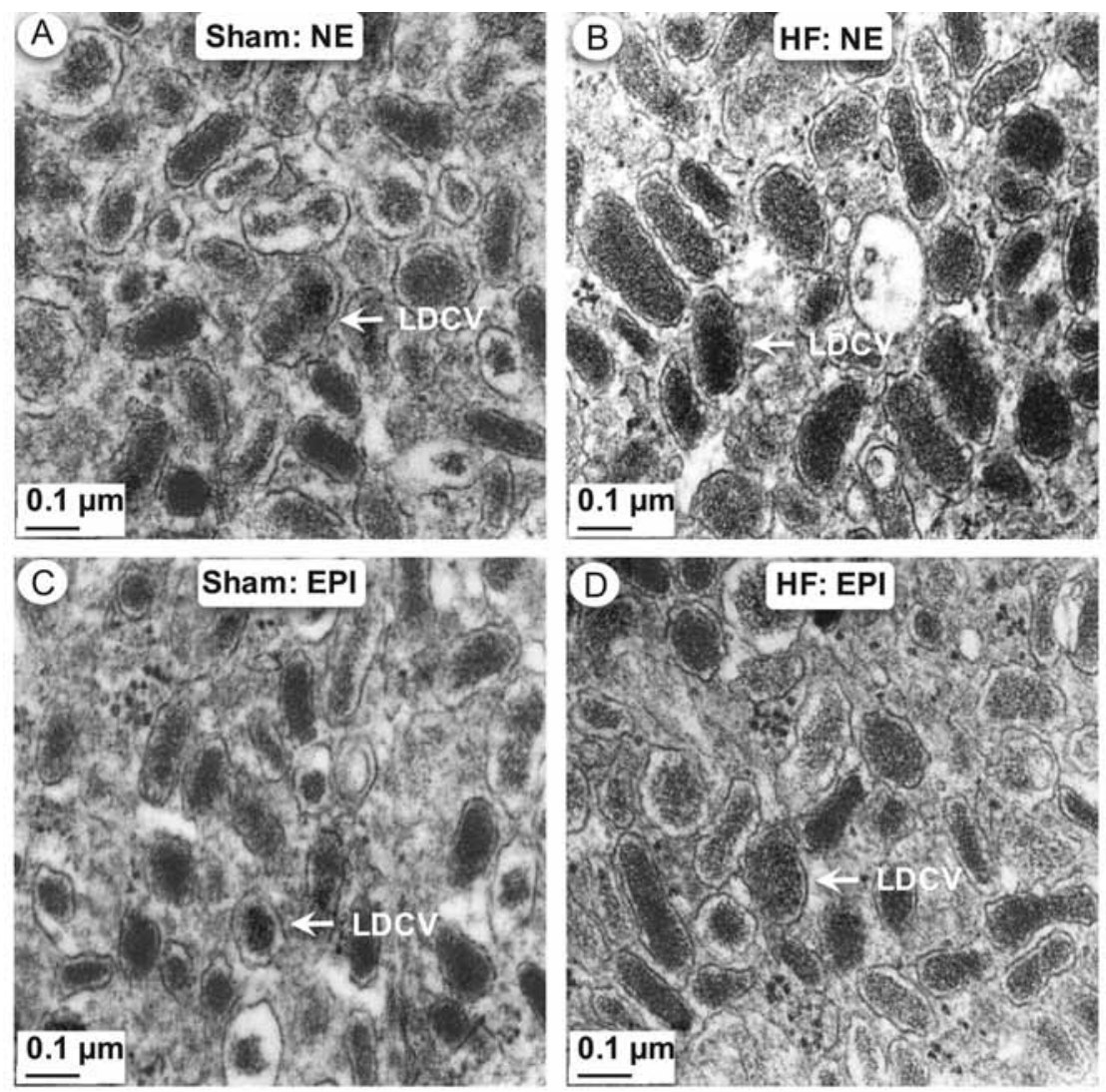

E

$$
\begin{aligned}
& \text { Sham } \\
& \text { D HF }
\end{aligned}
$$

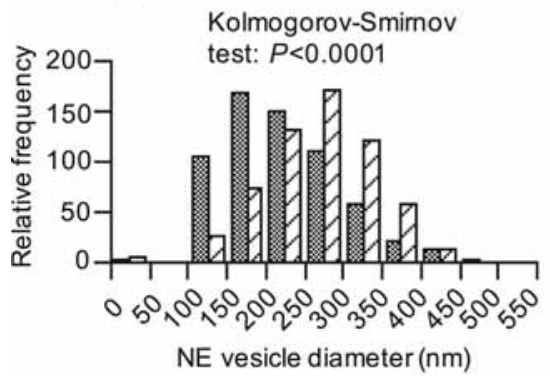

$\mathrm{F}$
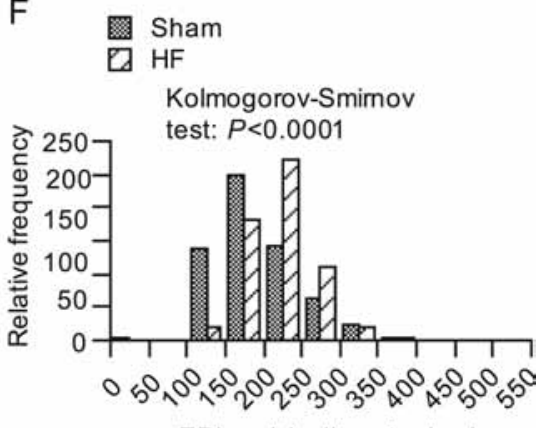

EPI vesicle diameter $(\mathrm{nm})$

\section{Figure 6}

High magnification $(\times 15,000$ original magnification) TEM photographs of the adrenal medulla. (A) Adrenal medulla showing NE cells with LDCV in a sham-operated rat. (B) Adrenal medulla showing NE cells with LDCV in an HF rat. (C) Adrenal medulla showing EPI cells with LDCV in a sham-operated rat. (D) Adrenal medulla showing EPI cells with LDCV in an HF rat. Morphometric analyses were carried out in 650 vesicles total from 3 each of the shamoperated and $\mathrm{HF}$ rats. Relative frequency distribution of NE-LDCV diameter (E) and EPI-LDCV diameter (F) are shown. Note highly significant $(P<0.0001)$ right shift in the distribution of NE and EPI vesicular diameter with heart failure.
$(26.7 \pm 5.3 \mathrm{HF}$ vs $12.5 \pm 1.3 \mathrm{mg}$ sham, $P<0.05)$ (Fig. $2 \mathrm{~A})$. Likewise, catecholamine (NE, EPI and DA) contents in the adrenal glands (Fig. 2B-D) were higher in HF rats compared with sham-operated rats. Adrenal NE content was significantly greater in $\mathrm{HF}$ rats compared with sham-operated controls $(325 \pm 35$ vs $168 \pm 36 \mathrm{ng} / \mathrm{mg}$, $P<0.05)$. Adrenal EPI was $404 \pm 63 \mathrm{HF}$ vs $202 \pm 41 \mathrm{ng} / \mathrm{mg}$ sham $(P<0.05)$. Adrenal DA was $46 \pm 12 \mathrm{HF}$ vs $18 \pm 2 \mu \mathrm{g} / \mathrm{g}$ sham $(P<0.05)$.

\section{Urinary norepinephrine excretion measurements}

Urinary NE excretion was significantly greater in $\mathrm{HF}$ rats compared with sham-operated controls as an index of overall sympathetic activation $(7.8 \pm 2.3 \mathrm{HF}$ vs $3.2 \pm 1.8 \mu \mathrm{g} /$ day sham, $P<0.05$ ) (Fig. $2 \mathrm{E}$ ).

\section{Increased adrenal expression of catecholamine biosynthetic enzymes in HF rats}

Consistent with the increased adrenal catecholamine contents in the adrenal glands in HF rats, the transsynaptic induction caused significant increase in mRNA and protein expressions of catecholamine biosynthetic enzymes such as TH, D $\beta H$, and PNMT in HF rats compared with sham-operated rats (Fig. 3A and B). It is of particular note that there was more than 30-fold increase in the message for PNMT in HF rats. 

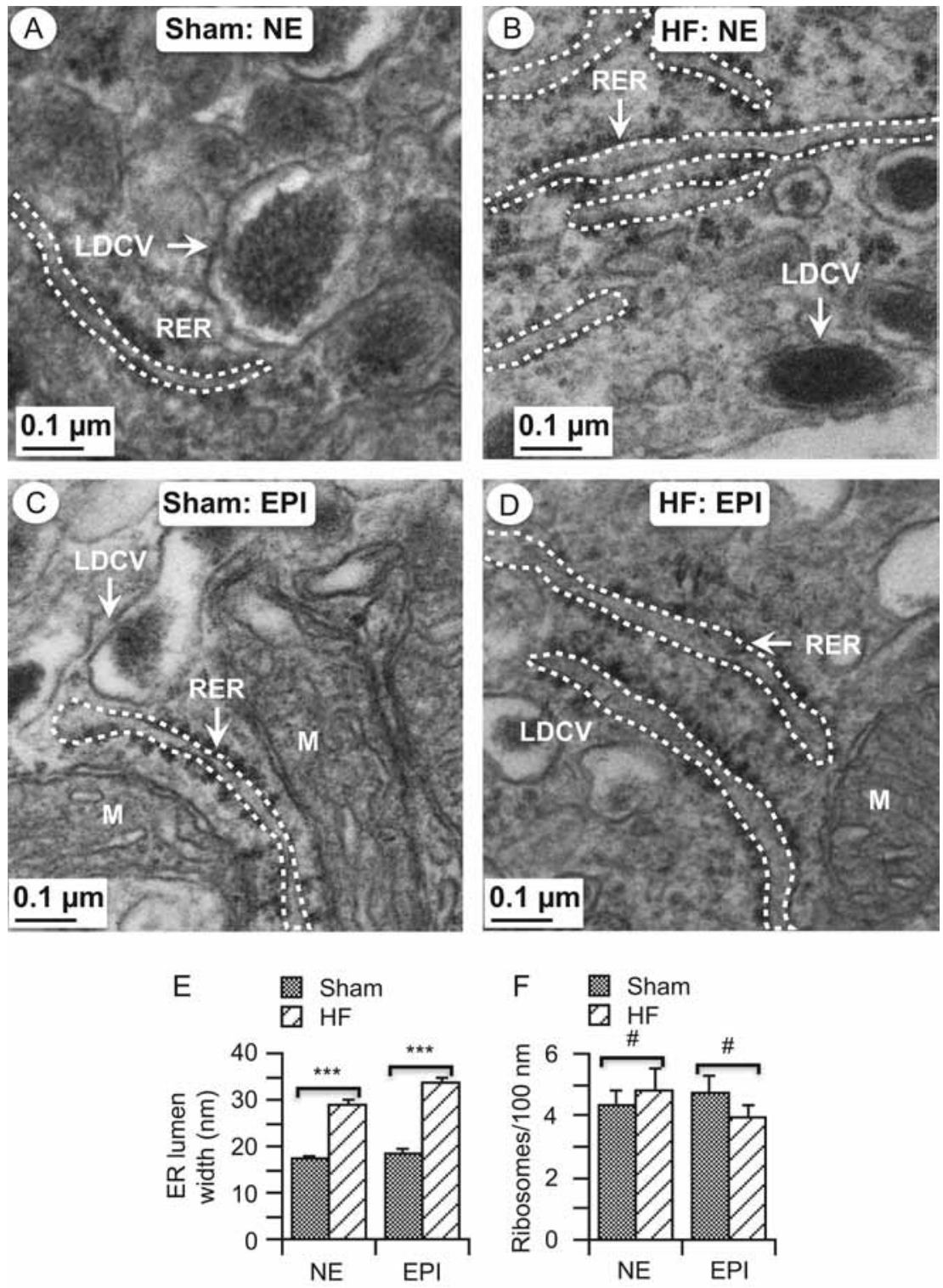

\section{Figure 7}

High magnification $(\times 15,000$ original magnification) TEM photographs of rough endoplasmic reticulum (RER). (A) NE cells showing RER and LDCV in a sham-operated rat. (B) NE cells showing RER (dilated) and LDCV in an HF rat. (C) EPI cells showing RER and LDCV in a sham-operated rat. (D) EPI cells showing RER (dilated) and LDCV in an HF rat. Morphometric analyses (2 RER per chromaffin cell for a total of 60 RER in 30 cells from 3 each of the sham-operated and HF rats). (E) Average ER lumen width (nm). (F) Average ribosomes per $100 \mathrm{~nm}$ length of ER. ${ }^{* *} P<0.001$; \# not significant.

\section{Splanchnic nerve terminal and synaptic vesicles}

The splanchnic-adrenal synapse contains two types of vesicles: clear SSV (presumably cholinergic) and SDCV (presumably peptidergic) (Coupland 1965, Smith \& Eiden 2012). In sham-operated rats, we observed SSV in the splanchnic-adrenal synapse (Fig. 4). However, in rats with HF, we found SSV and SDCV in the splanchnicadrenal synapse. In addition to SDCV, we found significant increased SSV in HF rats.

\section{Increased volume density, vesicle area and vesicle diameter of NE and EPI granules in HF rats}

As shown previously in mouse adrenal medulla (Pasqua et al. 2016), the NE-storing vesicles in rats were characterized by typical intensely electron-dense granules, some of which displaying a flattened or tubular appearance (Fig. 5A and B). In contrast, the EPI-storing vesicles were moderately electron dense and smaller in size (Fig. 5C and D). Although there were no changes in numerical density of the LDCV in chromaffin cells between sham-operated and HF rats (Fig. 5F), HF rats displayed increased LDCV volume density (Fig. 5E) coupled with increased LDCV area (Fig. 5G) and LDCV diameter (Fig. 5H) compared with sham-operated rats.

\section{Relative frequency distribution of NE-LDCV and EPI-LDCV in sham and HF rats}

While 100-250 nm LDCV diameters of NE-storing cells predominate in sham-operated rats, the preponderant

Published by Bioscientifica Ltd. 

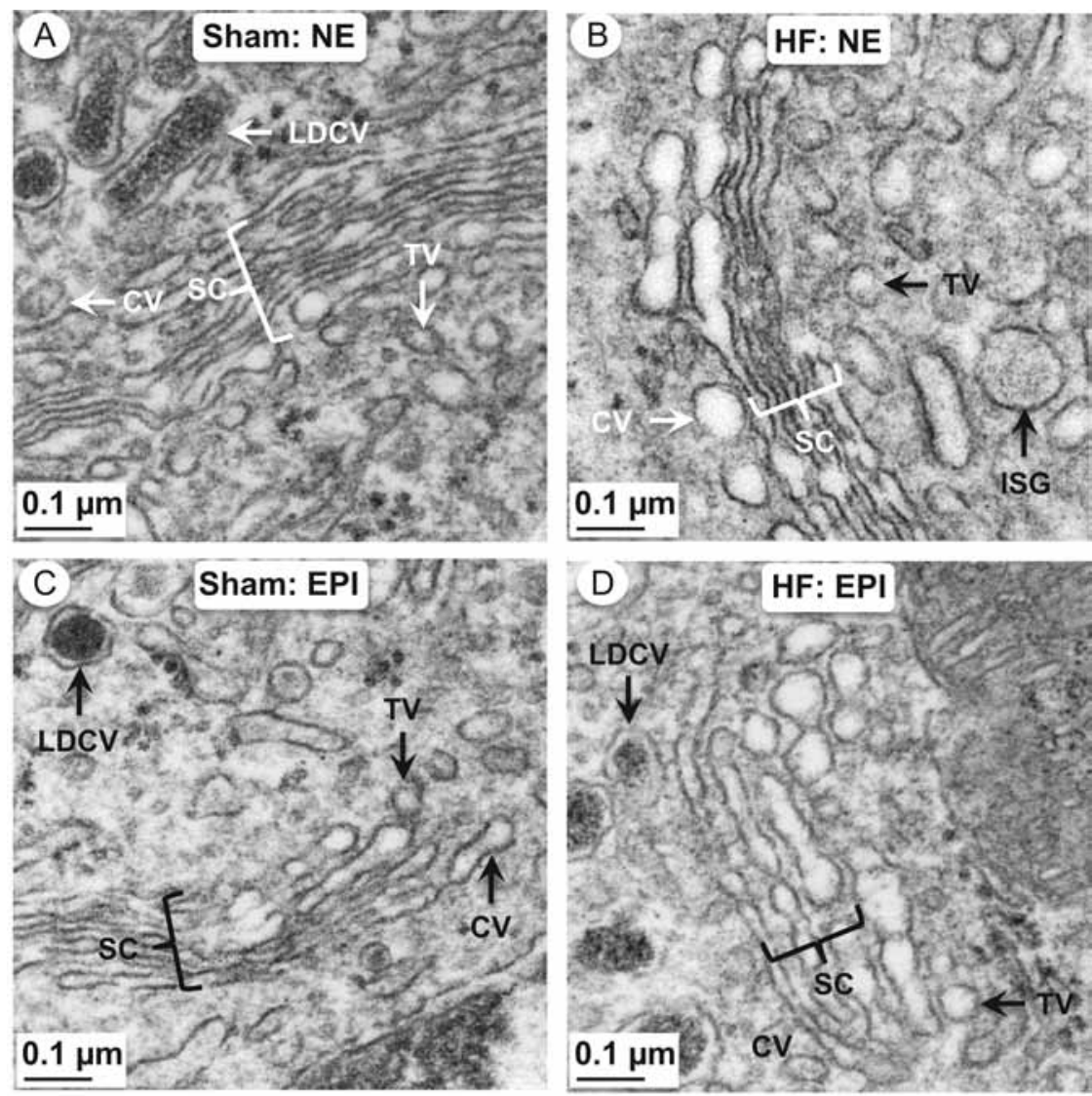

\section{E

$$
\text { 그․ Sham }
$$$$
\text { ש] HF }
$$

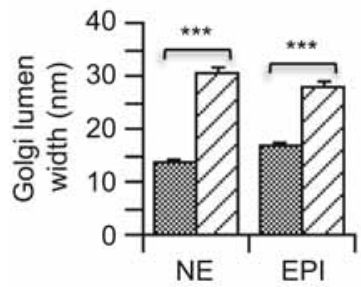

Figure 8

High-magnification $(\times 15,000$ original magnification) TEM photographs of Golgi complex (GC). (A) NE cells showing GC and LDCV in a sham-operated rat. (B) NE cells showing GC (dilated) and ISG in an HF rat. (C) EPI cells showing GC and LDCV in a sham-operated rat. (D) EPI cells showing GC (dilated) and LDCV in an $\mathrm{HF}$ rat. Morphometric analyses (1 GC per chromaffin cell for a total of $60 \mathrm{GC}$ from 3 each of the sham-operated and $\mathrm{HF}$ rats). (E) Average GC lumen width. CV, cis-Golgi vesicles; ISG, immature secretory granule; TV, trans-Golgi vesicle; SC, stacked-Golgi cisternae. ${ }^{* *} P<0.001$.
LDCV diameters in HF rats ranged from 250 to $400 \mathrm{~nm}$ (Fig. 6A, B and E). Kolmogorov-Smirnov test revealed highly significant right shift in the distribution of vesicular diameter with heart failure (KolmogorovSmirnov $\mathrm{D}=0.29 ; \quad P<0.0001)$. Similarly, LDCV diameters in EPI-storing vesicles were higher in HF rats $(200-300 \mathrm{~nm})$ compared with sham-operated rats (Fig. 6C, D and F). Like NE vesicles, there was a significant right-ward shift in the distribution of EPI vesicular diameters in rats with heart failure as evaluated by Kolmogorov-Smirnov test (KolmogorovSmirnov $\mathrm{D}=0.36 ; P<0.0001)$.

\section{Rough endoplasmic reticulum (RER) and Golgi complex (GC)}

ER regulates the synthesis, folding and maturation of secreted and transmembrane proteins and the storage of $\mathrm{Ca}^{2+}$, lipid biosynthesis and redox homeostasis (Oakes \& Papa 2015). Since HF rats suffer from prolonged stress, the adrenal medulla synthesized and secreted more catecholamines compared with sham-operated rats to cope with the stress situation. Increased catecholamine synthesis requires increased synthesis of catecholamine biosynthetic enzymes. Consistent with the above, HF rats displayed increased RER lumen width in both NE

Published by Bioscientifica Ltd. 

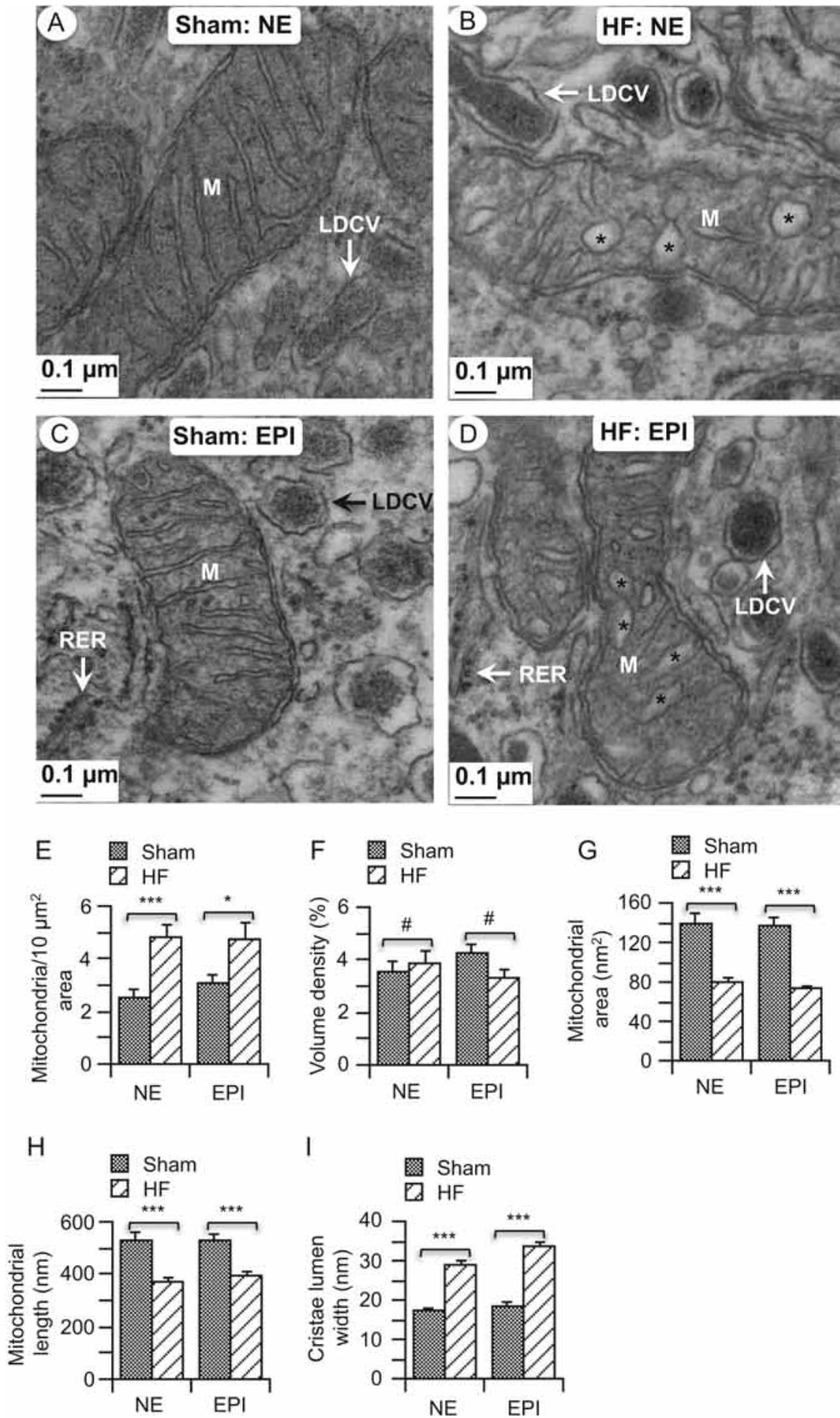

Figure 9

High-magnification (x15,000 original magnification) TEM photographs of mitochondria. (A) NE cells showing tubulo-lamellar mitochondria and LDCVs in a sham-operated rat. (B) NE cells showing a tubulo-vesicular mitochondrion and LDCVs in an HF rat. (C) EPI cells showing a tubulo-lamellar mitochondrion and LDCVs in a sham-operated rat. (D) EPI cells showing tubulo-vesicular mitochondria and LDCVs in an HF rat. Morphometric analyses (60 mitochondria total from 3 each of the sham-operated and $\mathrm{HF}$ rats): (E) Average mitochondria numbers per $10 \mu \mathrm{m}^{2}$ area of the cytoplasm. (F) Average mitochondrial volume density (\%). (G) Average mitochondrial area $\left(\mathrm{nm}^{2}\right)$. (H) Average mitochondrial length $(\mathrm{nm})$. (I) Average cristae lumen width $(\mathrm{nm}) .{ }^{*} P<0.05$ $* * * P<0.001$; \# not significant. and EPI storing cells compared with sham-operated rats (Fig. 7A-E). Surprisingly, ribosomal numerical density did not change between HF and sham-operated rats (Fig. 7F).

GC is the site of processing, packaging and sorting of proteins and lipids en route from the ER to the plasma membrane and other destinations (Sengupta \& Linstedt 2011). Increased catecholamine synthesis in HF rats would require formation of more vesicles for catecholamine storage. This increased workload has resulted in dilation of GC lumen in HF rats compared with sham-operated rats (Fig. 8A-E). 

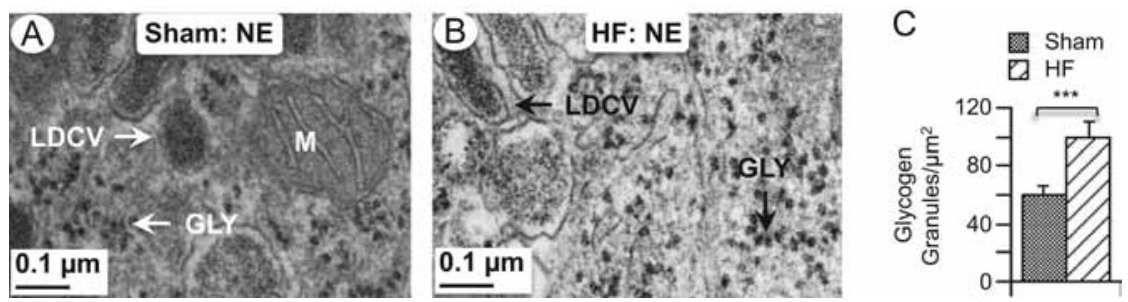

\section{Figure 10}

High-magnification $(\times 15,000$ original magnification) TEM photographs showing glycogen granules. (A) NE cells showing glycogen granules, LDCVs and mitochondrion in a sham-operated rat. (B) NE cells showing glycogen granules and LDCVs in an HF rat. (C) Morphometric data (60 cells total from 3 each of the sham-operated and $\mathrm{HF}$ rats) showing number of glycogen granules per $\mu \mathrm{m}^{2}$ of the cytoplasm. ${ }^{* *} P<0.001$.

\section{Mitochondrial lengths, volume and numerical densities and cristae volume density}

Mitochondria regulates the life and death of a cell by providing the enzymes and structural framework for generation of adenosine triphosphate (ATP), which serves as the energy currency of the cell (Scheffler 2008). Mitochondria in NE- and EPI-storing sham-operated rats showed the typical tubulo-lamellar appearance (Fig. 9A and C). In HF rats, mitochondrial cristae were dilated and looked like tubulo-vesicular mitochondria (Fig. 9B and D). Since increased ATP synthesis is required to counteract the prolonged stress, HF rats responded by increased biogenesis of mitochondria as shown by increased mitochondrial numerical density (Fig. 9E), which is accompanied by decreased mitochondrial area (Fig. 9G) and length (Fig. 9H). Despite increased mitochondrial numerical density in HF rats, there was no change in mitochondrial volume density (Fig. 9F) because of the smaller mitochondrial area (Fig. 9E-G). In addition to increased biogenesis of mitochondria, HF rats showed increased cristae lumen width to meet the increased energy demand in HF rats (Fig. 9I).

\section{Changes in glycogen granules}

At the ultrastructural level, glycogen appears as roughly circular granules from 150 to $400 \AA$ in diameter (Revel et al. 1960). Nutrient (high-fat diet) and hyperadrenergic (increased plasma catecholamines) stress appear to increase storage of glycogen for steady glucose supply to meet the high-energy demand (Pasqua et al. 2016). Consistent with the above stressors, we found an increased number of glycogen granules in HF rats compared with sham-operated rats (Fig. 10A-C).

\section{Discussion}

This study provides novel electron micrographic evidence to characterize the fundamental changes in the adrenomedullary chromaffin cells related to the status of the sympathetic nervous system activation during the HF condition. First, conscious undisturbed rats with HF display an enhanced adrenal medullary activity in rats with HF. Second, SDCV (possibly containing pituitary adenylate cylase-activating peptide (PACAP) and vasoactive intestinal peptide (VIP)) in splanchnicadrenal synapse of HF rats aids in maintaining long-term catecholamine secretion using secretory mechanisms different from that of acetylcholine. Third, increased ER and Golgi lumen width in HF rats are consistent with the demand of increased catecholamine synthesis and release. Fifth, more mitochondria with dilated cristae suggest increased ATP production, which is required for increased LDCV priming and subsequent exocytosis in rats with HF. Sixth, increased glycogen content in HF rats is indicative of a metabolic switch to accommodate the HF-induced prolonged stress. Taken together, these data provide a comprehensive characterization of the adaptive changes indicative of increased machinery for enhanced adrenal activity in the adrenal medullary chromaffin cells to provide chronic activation of the adrenal medulla during the chronic HF condition.

The adrenal medulla is innervated by preganglionic sympathetic neurons that are located in the intermediolateral cell column of the thoracic spinal cord and extend out to the adrenal medulla through thoracic splanchnic nerves (Wakade 1988, Mahata et al. 2000). The splanchnic-adrenal synapse contains both cholinergic (such as acetylcholine in SSV) and peptidergic (such as PACAP, VIP and secretin in SDCV) neurotransmitters (Wakade 1988, Guo \& Wakade 1994, Taupenot et al. 1998, Mahata et al. 2000). While acetylcholine stimulates the

Published by Bioscientifica Ltd. 
secretion of NE and EPI, PACAP and VIP predominantly stimulate the secretion of EPI (Guo \& Wakade 1994). The low-frequency splanchnic nerve firing (mainly by acetylcholine) causes catecholamine secretion from the adrenal medulla at a modest rate to maintain basal functioning. In contrast, the high-frequency firing (mainly PACAP and also acetylcholine) associated with emergency (stress) responses induce the adrenal medulla to secrete catecholamines at an elevated rate to combat with the perceived stress situation (Smith \& Eiden 2012, Stroth et al. 2013).

Consistent with the above findings and hypothesis, we found SDCV (possibly containing PACAP and VIP) in splanchnic-adrenal synapse of HF rats. Existing literature suggest that PACAP maintains long-term catecholamine secretion using secretory mechanisms different from that of acetylcholine (rapidly desensitizing) and via induction of the catecholamine biosynthetic enzymes such as TH, D $\beta \mathrm{H}$ and PNMT (Taupenot et al. 1999, Smith \& Eiden 2012, Stroth et al. 2013). Consistent with this idea in fact, increased mRNA levels of TH and PNMT in HF have been reported previously in pig (Tomaszek et al. 2015). Coherent with this, in fact, the trans-synaptic induction caused a dramatic and significant increase in $\mathrm{TH}, \mathrm{D} \beta \mathrm{H}$ and PNMT mRNA expression as well as protein in rats with HF. This upregulation was likely triggered by enhanced sympathetic tone commonly reported in HF.

Catecholamine secretion from adrenal medullary chromaffin cells is influenced by both cholinergic and peptidergic stimuli conducted by preganglionic sympathetic neurons that are located in the intermediolateral cell column of the thoracic spinal cord and extend to the adrenal medulla through thoracic splanchnic nerves (Mirkin 1961). The splanchnicadrenal synapse contains two types of vesicles: clear SSV (presumably cholinergic) and SDCV (presumably peptidergic) (Coupland 1965, Smith \& Eiden 2012). Cholinergic (acetylcholine) and peptidergic (such as PACAP and VIP) transmitters are preferentially released from this splanchnic-adrenal synapse: acetylcholine from SSV is released during low-frequency firing to release catecholamines at a modest rate for basal functioning; PACAP is released from SDCV along with acetylcholine during high-frequency firing upon stressinduced heightened sympathetic activation and releases catecholamines from LDCV at a much higher rate to accommodate the stress situation (Smith \& Eiden 2012). In this study, we found normal levels of SSV in the splanchnic-adrenal synapse in sham-operated rats, whereas in rats with $\mathrm{HF}$, we found a significant increase in SSV and SDCV in the splanchnic-adrenal synapse. These data indicate that the preganglionic sympathetic innervation to the adrenal medulla is primed for overactivation and sustained activation in rats with HF. It is likely that the increased SSV and SDCV aid in the chronic long-term activation of the adrenal medullary chromaffin cells in the chronic HF condition.

The body responds to stress by activating two hormonal systems: (1) the hypothalamus-pituitaryadrenal (HPA) axis, which causes the release of corticotrophin-releasing hormone $(\mathrm{CRH})$ from the hypothalamus, followed by adrenocorticotrophic hormone (ACTH) from the anterior pituitary in response to $\mathrm{CRH}$ and finally cortisol (human) or corticosterone (rodents) from the adrenal cortex in response to ACTH and (2) brainstem catecholaminergic neurons and spinal cord efferent activates the sympathetic nervous system and adrenal medulla to secrete NE (from the sympathetic nervous system and adrenal medulla) and EPI (from the adrenal medulla) (Tank \& Lee Wong 2015). As shown previously in adrenal medulla, the NE-storing vesicles are typically characterized by intense electron-dense granules, some of which displaying a flattened or tubular appearance. In contrast, the EPI-storing vesicles are moderately electron dense and smaller in size (Pasqua et al. 2016). This distinction allowed us to quantify the changes in these two distinct types of chromaffin cells in rats with $\mathrm{HF}$.

The stress-induced release of NE and EPI varies dramatically in response to various stressors. For example, insulin-induced hypoglycemia or 2-deoxyglucoseinduced glucoprivation causes profound release of EPI (by 10- to 30-fold) compared with a modest release of NE (by twofold) (Blandini et al. 1995, Elman et al. 2001). Surgical stress also causes profound release of EPI (Mannelli et al. 1982). In contrast, cold stress causes more release of NE than EPI (Johnson et al. 1977). Differential release of NE and EPI in response to different stressors has also been documented in animal studies (Pacak et al. 1998). In $\mathrm{HF}$, there is general overactivation of the sympathetic nervous system. In mice, HF causes release of more NE (by 7.5-fold) and EPI (by 2.8-fold) (Kamal et al. 2014). This is indicative of an elevated overall sympathoexcitation to the general circulation during HF. It is of interest to note that previously we have shown that CgA-deficient Chga-KO mice also suffer from persistent systematic stress due to increased secretion of catecholamines compared with WT mice, which leads to hypertension and also demonstrates majority of the morphological changes that are observed in the hypersympathetic state observed in

Published by Bioscientifica Ltd. 
the HF condition in this study (Pasqua et al. 2016). This suggests an intriguing overarching global conclusion that hyperactivated sympathetic state, regardless of its initial cause or origin can demonstrate similar morphological changes in the activated adrenal glands dictating catecholamine synthesis, storage and release.

It should be noted that there is strong evidence for a regionally heterogeneous pattern of sympathetic activation that appears to be targeted to specific tissues in experimental HF. Increased NE spillover from heart and kidney (but not lung) (Hasking et al. 1986, Eisenhofer et al. 1996, Rundqvist et al. 1997) and increased burst number in postganglionic sympathetic efferent to the vasculature of skeletal muscle (Ferguson et al. 1990) have been described in clinical HF. We have previously shown an increased turnover of $\mathrm{NE}$ in the heart, kidney and skeletal muscle, but not in spleen and liver in rats with HF (Patel et al. 2000). NE turnover can be influenced by any event that affects synthesis, release, uptake or breakdown of NE at the noradrenergic nerve terminal. For example, increased circulating or local angiotensin II levels in HF could stimulate NE release from peripheral sympathetic nerve endings (Clemson et al. 1994, Driessen \& Starke 1994), thus promoting increased NE turnover. Noradrenergic processes at the level of nerve terminal that are independent of neural activity appear to be unaltered in rats with $\mathrm{HF}$, which also implicates centrally mediated neural mechanisms in causing the regional increases in NE turnover. In this study, the changes in the adrenal medulla appear to be dictated by an overactive state during HF.

This study shows a significant activation of the adrenal medulla of rats with HF. The close parallel between the results of these studies and the clinical literature strengthens the contention that sympathetic activation of some (but not all) tissues accompanies HF. Our findings in rats are also consistent with the findings in mice, where more plasma catecholamines are compensated by more resynthesis (as evidenced by more NE and EPI in the adrenal gland) (Kamal et al. 2014). We found increased volume density, LDCV area and LDCV diameter for both NE-storing cells as well as EPI-storing vesicles in HF rats compared with sham rats. These results indicate the increased machinery for enhanced adrenal activity in rats with HF.

The findings of increased ER (for synthesis of more catecholamine biosynthetic enzymes and SNARE proteins involved in exocytosis) and Golgi lumen (for formation of more catecholamine storage vesicles) width in HF rats are consistent with the demand of increased catecholamine synthesis and release. In the chronic HF condition, elevated plasma levels of catecholamines would require additional synthesis and release that perhaps are maintained by this increased ER in the chromaffin cells.

The peroxisome proliferator-activated receptor- $\gamma$ $(\operatorname{PPAR} \gamma)$ coactivator $1 \alpha$ (PGC-1 $\alpha)$ is a major regulator of exercise-induced phenotypic adaptation and substrate utilization. A modest ( 25\%) upregulation of PGC- $1 \alpha$ improves mitochondrial biogenesis and fatty acid oxidation in healthy and insulin-resistant skeletal muscle. It has been reported that PGC- $1 \alpha$ is involved in the coordinated regulation of nuclear- and mitochondrialencoded genes required for contractile and metabolic adaptations in skeletal muscle (Puigserver \& Spiegelman 2003, Scarpulla 2008, Wende et al. 2007). Of note, PGC-1 $\alpha$ expression per se is also regulated by PGC- $1 \alpha$ via its interaction with MEF2 (Handschin et al. 2003). Based on the above literature, we believe that increased mitochondrial biogenesis in NE and EPI cells in HF rats is due to increased expression of PGC- $1 \alpha$ (Karamanlidis et al. 2010, Ahuja et al. 2013). Decreased mitochondrial area and diameter without any change in mitochondrial volume density are indicative of more but smaller mitochondria in HF rats. Cellular respiration takes place in the mitochondrial cristae where biochemical energy from nutrients is converted into ATP, the energy currency of the cell. In response to increased energy demand, cristae increase its surface area by increasing cristae lumen width to produce more ATP. Thus, dilated cristae in HF rats are consistent with increased ATP production required for increased LDCV priming and consequent exocytosis (Rettig \& Neher 2002).

Heart switches from less energetically efficient fatty acids substrate to more energetically efficient carbohydrate substrate for ATP production to protect the myocardium under ischemic conditions (Neubauer 2007, Aragones et al. 2009). Similar metabolic switch for ATP production also takes place in cancer cells (Vander Heiden et al. 2009). Therefore, increased glycogen content in the chromaffin cells of the adrenal medulla from the rats with HF may indicate a metabolic switch from fatty acid to carbohydrate metabolism to counteract HF-induced prolonged synthesis and release of catecholamines by the chromaffin cells.

In summary, the adrenal medulla is activated during the chronic HF condition. These electron micrographic observation indicates that the chronic HF condition provokes increased basal SDCV (possibly containing PACAP and VIP) in splanchnic-adrenal synapse of HF rats promoting toward the maintenance of long-term

Published by Bioscientifica Ltd 
catecholamine secretion, increased ER and Golgi lumen width to accommodate the enhanced demand for increased catecholamine synthesis and release, and more mitochondria with dilated cristae and glycogen to adapt to the increased energy demand for the increased biogenesis and exocytosis of catecholamines from the adrenal medulla. Thus, although centrally mediated sympathetic activation accompanies chronic HF, the results in this study demonstrates heterogeneity of adaptive changes within the adrenal chromaffin cells that likely contribute to the functional consequences of chronic elevations in plasma catecholamines in pathophysiological state of chronic HF.

\section{Declaration of interest}

The authors declare that there is no conflict of interest that could be perceived as prejudicing the impartiality of the research reported.

\section{Funding}

This work was supported by the National Institutes of Health grants R56 HL124104 and P01 HL62222.

\section{References}

Ahuja P, Wanagat J, Wang Z, Wang Y, Liem DA, Ping P, Antoshechkin IA, Margulies KB \& Maclellan WR 2013 Divergent mitochondrial biogenesis responses in human cardiomyopathy. Circulation 127 1957-1967. (doi:10.1161/CIRCULATIONAHA.112.001219)

Aragones J, Fraisl P, Baes M \& Carmeliet P 2009 Oxygen sensors at the crossroad of metabolism. Cell Metabolism 9 11-22. (doi:10.1016/ j.cmet.2008.10.001)

Blandini F, Martignoni E, Sances E, Bono G \& Nappi G 1995 Combined response of plasma and platelet catecholamines to different types of short-term stress. Life Sciences 56 1113-1120. (doi:10.1016/ 0024-3205(95)00048-B)

Brändle M, Patel KP, Wang W \& Zucker IH 1996 Hemodynamic and norepinephrine responses to pacing-induced heart failure in conscious sinoaortic-denervated dogs. Journal of Applied Physiology 81 1855-1862.

Clemson B, Gaul L, Gubin SS, Campsey DM, McConville J, Nussberger J \& Zelis R 1994 Prejunctional angiotensin II receptors. Facilitation of norepinephrine release in the human forearm. Journal of Clinical Investigation 93 684-691. (doi:10.1172/JCI117021)

Cohn JN, Levine TB, Olivari MT, Garberg V, Lura D, Francis GS, Simon AB \& Rector T 1984 Plasma norepinephrine as a guide to prognosis in patients with chronic congestive heart failure. New England Journal of Medicine 311 819-823. (doi:10.1056/ NEJM198409273111303)

Coupland RE 1965 Electron microscopic observations on the structure of the rat adrenal medulla: II. Normal innervation. Journal of Anatomy 99 255-272.

de Lucia C, Femminella GD, Gambino G, Pagano G, Allocca E, Rengo C, Silvestri C, Leosco D, Ferrara N \& Rengo G 2014 Adrenal adrenoceptors in heart failure. Frontiers in Physiology 5246. (doi: 10.3389/fphys.2014.00246)
Driessen B \& Starke K 1994 Modulation of neural noradrenaline and ATP release by angiotensin II and prostaglandin $\mathrm{E}_{2}$ in guinea-pig vas deferens. Naunyn Schmiedebergs Archives of Pharmacology 350 618-625.

Eisenhofer G, Friberg P, Rundqvist B, Quyyumi AA, Lambert G, Kaye DM, Kopin IJ, Goldstein DS \& Esler MD 1996 Cardiac sympathetic nerve function in congestive heart failure. Circulation 93 1667-1676. (doi:10.1161/01.CIR.93.9.1667)

Elman I, Goldstein DS, Adler CM, Shoaf SE \& Breier A 2001 Inverse relationship between plasma epinephrine and testosterone levels during acute glucoprivation in healthy men. Life Sciences 68 1889-1898. (doi:10.1016/S0024-3205(01)00982-1)

Ferguson DW, Berg WJ \& Sanders JS 1990 Clinical and hemodynamic correlates of sympathetic nerve activity in normal humans and patients with heart failure: evidence from direct microneurographic recordings. Journal of the American College of Cardiology 16 1125-1134. (doi:10.1016/0735-1097(90)90544-Y)

Goldstein DS, Eisenhofer G \& Kopin IJ 2003 Sources and significance of plasma levels of catechols and their metabolites in humans. Journal of Pharmacology and Experimental Therapeutics 305 800-811. (doi:10.1124/jpet.103.049270)

Guo X \& Wakade AR 1994 Differential secretion of catecholamines in response to peptidergic and cholinergic transmitters in rat adrenals. Journal of Physiology 475 539-545. (doi:10.1113/jphysiol.1994. sp020092)

Handschin C, Rhee J, Lin J, Tarr PT \& Spiegelman BM 2003 An autoregulatory loop controls peroxisome proliferator-activated receptor gamma coactivator 1alpha expression in muscle. PNAS 100 7111-7116. (doi:10.1073/pnas.1232352100)

Hasking GJ, Esler MD, Jennings GL, Burton D \& Korner PI 1986 Norepinephrine spillover to plasma in patients with congestive heart failure: evidence of increased overall and cardio-renal sympathetic nervous activity. Circulation 73 615-621. (doi:10.1161/ 01.CIR.73.4.615)

Johnson DG, Hayward JS, Jacobs TP, Collis ML, Eckerson JD \& Williams RH 1977 Plasma norepinephrine responses of man in cold water. Journal of Applied Physiology: Respiratory, Environmental and Exercise Physiology 43 216-220.

Kamal FA, Mickelsen DM, Wegman KM, Travers JG, Moalem J, Hammes SR, Smrcka AV \& Blaxall BC 2014 Simultaneous adrenal and cardiac g-protein-coupled receptor-gbetagamma inhibition halts heart failure progression. Journal of the American College of Cardiology 63 2549-2557. (doi:10.1016/j.jacc.2014.02.587)

Karamanlidis G, Nascimben L, Couper GS, Shekar PS, del Monte F \& Tian R 2010 Defective DNA replication impairs mitochondrial biogenesis in human failing hearts. Circulation Research 106 1541-1548. (doi:10.1161/CIRCRESAHA.109.212753)

Kleiber AC, Zheng H, Schultz HD, Peuler JD \& Patel KP 2008 Exercise training normalizes enhanced glutamate-mediated sympathetic activation from the PVN in heart failure. American Journal of Physiology: Regulatory, Integrative and Comparative Physiology 294 R1863-1872. (doi: 10.1152/ajpregu.00757.2007)

Kline RL, Patel KP \& Mercer PF 1986 Enhanced noradrenergic activity in the kidney of brattleboro rats with diabetes insipidus. American Journal of Physiology 250 R567-R572.

Kvetnansky R, Weise VK, Thoa NB \& Kopin IJ 1979 Effects of chronic guanethidine treatment and adrenal medullectomy on plasma levels of catecholamines and corticosterone in forcibly immobilized rats. Journal of Pharmacology and Experimental Therapeutics 209 287-291.

Lymperopoulos A, Rengo G, Gao E, Ebert SN, Dorn GW, 2nd \& Koch WJ 2010 Reduction of sympathetic activity via adrenaltargeted GRK2 gene deletion attenuates heart failure progression and improves cardiac function after myocardial infarction. Journal of Biological Chemistry 285 16378-16386. (doi:10.1074/ jbc.M109.077859)

Mahata SK, Mahata M, Wakade AR \& O'Connor DT 2000 Primary structure and function of the catecholamine release inhibitory 
peptide catestatin (chromogranin A(344-364)): identification of amino acid residues crucial for activity. Molecular Endocrinology 14 1525-1535. (doi: 10.1210/me.14.10.1525)

Mannelli M, Gheri RG, Selli C, Turini D, Pampanini A, Giusti G \& Serio M 1982 A study on human adrenal secretion. Measurement of epinephrine, norepinephrine, dopamine and cortisol in peripheral and adrenal venous blood under surgical stress. Journal of Endocrinological Investigation 5 91-95. (doi: 10.1007/bf03350497)

Mirkin BL 1961 Factors influencing the selective secretion of adrenal medullary hormones. Journal of Pharmacology and Experimental Therapeutics 132 218-225.

Neubauer S 2007 The failing heart - an engine out of fuel. New England Journal of Medicine 356 1140-1151. (doi:10.1056/NEJMra063052)

Oakes SA \& Papa FR 2015 The role of endoplasmic reticulum stress in human pathology. Annual Review of Pathology 10 173-194. (doi:10.1146/annurev-pathol-012513-104649)

Pacak K, Palkovits M, Yadid G, Kvetnansky R, Kopin IJ \& Goldstein DS 1998 Heterogeneous neurochemical responses to different stressors: a test of Selye's doctrine of nonspecificity. American Journal of Physiology 275 R1247-1255.

Packer M 1988 Neurohormonal interactions and adaptations in congestive heart failure. Circulation 77 721-730. (doi:10.1161/01.CIR.77.4.721)

Pasqua T, Mahata S, Bandyopadhyay GK, Biswas A, Perkins GA, Sinha-Hikim AP, Goldstein DS, Eiden LE \& Mahata SK 2016 Impact of Chromogranin A deficiency on catecholamine storage, catecholamine granule morphology and chromaffin cell energy metabolism in vivo. Cell and Tissue Research 363 693-712. (doi:10.1007/s00441-015-2316-3)

Patel KP 1997 Neural regulation in experimental heart failure. Bailliere's Clinical Neurology 6 283-296.

Patel KP, Zhang K \& Carmines PK 2000 Norepinephrine turnover in peripheral tissues of rats with heart failure. American Journal of Physiology: Regulatory, Integrative and Comparative Physiology 278 R556-R562.

Puigserver P \& Spiegelman BM 2003 Peroxisome proliferator-activated receptor-gamma coactivator 1 alpha (PGC-1 alpha): transcriptional coactivator and metabolic regulator. Endocrine Reviews 24 78-90. (doi:10.1210/er.2002-0012)

Rengo G, Leosco D, Zincarelli C, Marchese M, Corbi G, Liccardo D, Filippelli A, Ferrara N, Lisanti MP, Koch WJ, et al. 2010 Adrenal GRK2 lowering is an underlying mechanism for the beneficial sympathetic effects of exercise training in heart failure. American Journal of Physiology: Heart and Circulatory Physiology 298 H2032-H2038. (doi: 10.1152/ajpheart.00702.2009)

Rettig J \& Neher E 2002 Emerging roles of presynaptic proteins in Ca++-triggered exocytosis. Science 298 781-785. (doi:10.1126/ science.1075375)

Revel JP, Napolitano L \& Fawcett DW 1960 Identification of glycogen in electron micrographs of thin tissue sections. Journal of Biophysical and Biochemical Cytology 8 575-589. (doi:10.1083/jcb.8.3.575)

Rundqvist B, Elam M, Bergmann-Sverrisdottir Y, Eisenhofer G \& Friberg P 1997 Increased cardiac adrenergic drive precedes generalized sympathetic activation in human heart failure. Circulation 95 169-175. (doi:10.1161/01.CIR.95.1.169)

Scarpulla RC 2008 Transcriptional paradigms in mammalian mitochondrial biogenesis and function. Physiological Reviews $\mathbf{8 8}$ 611-638. (doi:10.1152/physrev.00025.2007)
Scheffler IE 2008 Mitochondria. New York: John Wiley \& Sons, Inc.

Schneider J, Lother A, Hein L \& Gilsbach R 2011 Chronic cardiac pressure overload induces adrenal medulla hypertrophy and increased catecholamine synthesis. Basic Research in Cardiology 106 591-602. (doi:10.1007/s00395-011-0166-z)

Sengupta D \& Linstedt AD 2011 Control of organelle size: the Golgi complex. Annual Review of Cell and Developmental Biology 27 57-77. (doi:10.1146/annurev-cellbio-100109-104003)

Smith CB \& Eiden LE 2012 Is PACAP the major neurotransmitter for stress transduction at the adrenomedullary synapse? Journal of Molecular Neuroscience 48 403-412. (doi:10.1007/s12031-012-9749-x)

Stroth N, Kuri BA, Mustafa T, Chan SA, Smith CB \& Eiden LE 2013 PACAP controls adrenomedullary catecholamine secretion and expression of catecholamine biosynthetic enzymes at high splanchnic nerve firing rates characteristic of stress transduction in male mice. Endocrinology 154 330-339. (doi:10.1210/en.2012-1829)

Tank AW \& Lee Wong D 2015 Peripheral and central effects of circulating catecholamines. Comprehensive Physiology 5 1-15. (doi: 10.1002/cphy. c140007)

Taupenot L, Mahata M, Mahata SK \& O'Connor DT 1999 Timedependent effects of the neuropeptide PACAP on catecholamine secretion: stimulation and desensitization. Hypertension 34 1152-1162. (doi:10.1161/01.HYP.34.5.1152)

Taupenot L, Mahata SK, Wu H \& O'Connor DT 1998 Peptidergic activation of transcription and secretion in chromaffin cells. Cis and trans signaling determinants of pituitary adenylyl cyclase-activating polypeptide (PACAP). Journal of Clinical Investigation 101 863-876. (doi:10.1172/JCI1129)

Tomaszek A, Kiczak L, Bania J, Paslawska U, Zacharski M, Janiszewski A, Noszczyk-Nowak A, Dziegiel P, Kuropka P, Ponikowski P, et al. 2015 Increased gene expression of catecholamine-synthesizing enzymes in adrenal glands contributes to high circulating catecholamines in pigs with tachycardia-induced cardiomyopathy. Journal of Physiology and Pharmacology 66 227-231.

Vander Heiden MG, Cantley LC \& Thompson CB 2009 Understanding the Warburg effect: the metabolic requirements of cell proliferation. Science 324 1029-1033. (doi:10.1126/science.1160809)

Wakade AR 1988 Noncholinergic transmitter(s) maintains secretion of catecholamines from rat adrenal medulla for several hours of continuous stimulation of splanchnic neurons. Journal of Neurochemistry 50 1302-1308. (doi:10.1111/j.1471-4159.1988. tb10608.x)

Wende AR, Schaeffer PJ, Parker GJ, Zechner C, Han DH, Chen MM, Hancock CR, Lehman JJ, Huss JM, McClain DA, et al. 2007 A role for the transcriptional coactivator PGC-1alpha in muscle refueling. Journal of Biological Chemistry 282 36642-36651. (doi:10.1074/ jbc.M707006200)

Zhang K, Li YF \& Patel KP 2001 Blunted nitric oxide-mediated inhibition of renal nerve discharge within PVN of rats with heart failure. American Journal of Physiology: Heart and Circulatory Physiology 281 H995-H1004.

Zucker IH, Wang W, Brändle M, Schultz HD \& Patel KP 1995 Neural regulation of sympathetic nerve activity in heart failure. Progress in Cardiovascular Diseases 37 397-414. (doi: 10.1016/ s0033-0620(05)80020-9)

Received in final form 22 June 2016

Accepted 24 June 2016 http://joe.endocrinology-journals.org

DOI: 10.1530/JOE-16-0146
๑ 2016 Society for Endocrinology Printed in Great Britain 